\title{
The Names in Solzhenitsyn's Short Novel: One Day in the Life of Ivan Denisovich
}

\author{
ECKHARD RUTTNER
}

A

NUMBER OF ARTICLES have been devoted to Solzhenitsyn's connection with the classical Russian literary tradition. N. Pervushin draws parallels between Solzhenitsyn's One Day, Dostoevskii's Notes from the House of the Dead and Tolstoi's War and Peace. ${ }^{1}$ He also finds stylistical similarities between Solzhenitsyn's short novel and Chekhov's short stories. ${ }^{2}$ Vintila Horia speaks about formal traces which Tolstoi has left in Solzhenitsyn, but maintains that he has much more in common with Dostoevskii's humanity. ${ }^{3}$ Roman Gul finds similarities in the works of Solzhenitsyn and Remizov, ${ }^{4}$ whereas L. Koehler disputes this and links Solzhenitsyn's stories together with the tradition of Leskov. She compares Matrena, the heroine of the story Matrena's House, with Malania, the main figure of Leskov's story Malania-the Mutton Head and tries to pursue Leskovian elements in other stories: An Incident at the Krechetovka Station and For the Good of the Cause. ${ }^{5}$ A. Obolensky sees a similarity between Rusanov, one of the main figures of the novel Cancer Ward, and Tolstoi's Ivan Ilich in The Death of Ivan Ilich. ${ }^{6}$

G. Zhekulin maintains the view that Solzhenitsyn's stories reveal the stylistical influences of Turgenev. ${ }^{7}$ However, only a few scholars write about Solzhenitsyn's novels and short stories in terms of such literary techniques as composition, language and stylistical devices. ${ }^{8}$

${ }^{1}$ N.V. Pervushin, "The Soviet Writer Solzhenitsyn, His Critics and the Classical Russian Literature,”'Études Slaves et Est-Européennes, no. 1-2 (1965/66), pp. 5-8.

2 Ibid.

${ }^{3}$ V. Horia, "Solzhenitsin o el papel del escritor," La estafeta literaria, no. 503 (November 1, 1972), p. 5.

4 R. Gul, “Aleksander Solzhenitsyn i shkola Remizova,” New Review, LXXI (1963), p. 65.

${ }^{5}$ L. Koehler, "Aleksander Solzhenitsyn and Russian Literary Tradition," The Russian Review, no. 2 (April 1967), pp. 179-182.

'A. Obolensky, "Solzhenitsyn in the Main Stream of Russian Literature," Canadian Slavonic Papers, XIII, 2-3 (1971), p. 135.

7 G.N. Zhekulin, “Solzhenitsyn's four Stories," Soviet Studies, XVI, no. 1 (June 1964), pp. 52. 53.

- N.V. Pervushin, "Preliminary Remarks on the Literary Craft of Solzhenitsyn," Canadian Slavonic Papers, XIII, 2-3 (1971) pp. 141-146; J. Perelmuter, "The Language of Solzhenitsyn's Odin den' Ivana Denisovica" (unpublished master's thesis. McGill University, 1967); T.C. Vinokur, "O iazyke i stile povesti A.I. Solzhenitsyna Odin den' Ivana Denisovicha," Voprosy kultury rechi, VI (1965), pp. 16-32. 
The purpose of this article is to show how Solzhenitsyn uses in One Day names which carry special meanings, sometimes allegorical and sometimes denoting the character's function. At the conclusion of this article an attempt will be made to compare Solzhenitsyn's use of names with that of Gogol, an unsurpassed master in the technique of using names to characterize Russian and Ukrainian traits.

R. Pletnev emphasizes in his recent book on Solzhenitsyn that the naming in One Day in the Life of Ivan Denisovich is not accidental and that some names contain symbols:

We have already spoken about Ivan and Shukh [according to Pletnev Shukhov has been derived from shukh, shuga-ice, bacon], but today the sour Fetiukov is really a lout [fetiuk in Russian], the evil warder acts like a wolf and his name is Volkovoi [volk means in Russian wolf], the boisterous proud captain of the second rank is Buinovskii [buinyi means boisterous in Russian], the jumper, giddy and sharp guy is called Gopchik [gop means jump in Russian], the thin and tall guard-Poltora Ivana. No, there are many names which Solzhenitsyn did not use unintentionally in the short novel, and these sometimes contain symbols. ${ }^{9}$

Pletnev, however, mentions only a few names in Solzhenitsyn's One Day and does not draw conclusions as to why Solzhenitsyn used them.

Naming in a work of literature can be "the simplest form of characterization" 10 as Warren and Wellek point out. We observe Solzhenitsyn's device of characterizing names only in the short novel One Day. Personal names in his other stories and novels, (e.g., Dontsova, Nerzhin, Volodin, Rubin, Kostoglotov or Sologdin) do not reveal character. There the author finds other means of describing his figures. Solzhenitsyn uses names probably in order to hint at the character of his main figures, since the laconic style of One Day excludes almost by its name any lengthy description. Georg Lukács rightly speaks about the "main feature of the composition concentrated on the essential" and the "utmost economy in the process in narration" 11 and points to the strong symbolic effect of the novel. Many of the acting persons became symbolical figures.

Avoiding static descriptions, Solzhenitsyn develops the character of his protagonists through their actions with the names alluding to their

${ }^{9}$ R. Pletnev, A.I. Solzhenitsyn (Miunkhen, 1970), p. 22 (the quotation has been translated by the author of this article).

${ }^{10}$ R. Wellek and A. Warren, Theory of Literature (3rd ed. New York, 1962), p. 219.

${ }^{11}$ G. Lukács, Solzhenitsyn (Neuwied und Berlin, 1970), p. 12 (the quotation has been translated by the author of this article). 
main features. This method can be observed for example in connection with the main figure Shukhov, as it will be shown later. Lieutenant Volkovoi appears only once in the novel, but his name and behaviour, as mentioned by the narrator, give us an almost complete illustration of his character.

Solzhenitsyn rarely used nicknames, the only exceptions being presumably the guards Poltora Ivana (Big Ivan), Kurnosenkii (kurnosyi means "snub nose") and Khromi ("the lame"), who is in charge of the dining hall. The more important figures, however, Shukhov, Buinovskii, Tiurin and Fetiukov, have symbolic personal names although it is more difficult to recognize their meaning. For my attempt to interpret the names, I used the most relevant dictionaries of the Russian language. ${ }^{12}$

The name of the main hero, Ivan Denisovich Shukhov could have been theoretically derived from Shukh, shuga "fine ice, fat or bacon," as R. Pletnev pointed out. ${ }^{13}$ Dal' (IV 650), Ushakov (IV 1375) and the dictionary of the Academy of Science (IV 1005) mention shukhat' as equivalent to "frighten" or "scare" and shuga in the meaning of "fine ice." However, this explanation as well as the suggestion of Pletnev is not very convincing because certain passages in the story One Day reveal Shukhov's character differently. From the very beginning, Shukhov's practical instinct and his cleverness is revealed:

Shukhov never slept through reveille but always got up at once. That gave him about an hour and a half to himself before the morning roll call, a time when anyone who knew what was what in the camps could always scrounge a little something on the side. He could sew someone a cover for his mittens out of a piece of old lining. He could bring one of the big gang bosses his dry felt boots while he was still in his bunk, to save him the trouble of hanging around the pile of boots in his bare feet and trying to find his own. Or he could run around to one of the supply rooms where there might be a little job, sweeping or carrying something. ${ }^{14}$

Eight years of labour camp had exercised a strong influence on Shukhov's character, trivial things like a piece of broken saw becoming extremely important. A prisoner can make a knife out of it, lend it to other people and get a piece of bread in return. The sole interest of the internee is survival until his term is over, so he works only in order to se-

\footnotetext{
12 Akademiia Nauk SSSR, Slovar' russkogo iazyka (Moskva, 1957); D. Ushakov, Tolkovyi slovar' russkogo iazyka (Moskva, 1934); V. Dal', Tolkovyi slovar' zhivogo velikorusskogo iazyka (nabrano i napechatano so vtorogo izdaniia 1880-1882, Moskva, 1956).

${ }^{13}$ R. Pletnev, A.I. Solzhenitsyn, p. 12.

${ }^{14}$ A. Solzhenitsyn, trans. One Day in the Life of Ivan Denisovich, By R. Hingley and M. Hayward (New York, 1963), pp. 1-2.
} 
cure his food ration. He always looks for possibilities to ease his labour. The brutal camp life engenders cheating and the prisoner's thoughts are concentrated on small advantages, mainly on getting more food. Shukhov himself, despite his goodness and more or less timid character, is no exception and Tiurin, his brigade leader values his abilities, when he learns about his trick with the trowel: "Shukhov had a bright idea. 'You give yours to Gopchik so he can take'em over and I'll finish off the job with mine. They don't know I've got it so they won't have to check it in!' The boss laughed. 'What the hell are we going to do without you when you've served your time? We'll all be crying our hearts out for you'" (Hingley-Hayward, p. 123).

Shukhov is an experienced zek; he knows all the dodges and ways in the camp and profits mostly by situations in which other prisoners are careless; he often picks up an extra portion of kasha or a tray for the dishes. Symbolically he might embody the Russian peasant who behaves himself very cleverly in camp, but always remains a human being. $\mathrm{He}$ pleases influential persons in the camp, gets a reward for his services, but does not breach certain principles of honesty: e.g., he refuses to bribe or take bribes.

Probably Shukhov's name has been derived from an expression of Russian jargon, shukhovat', which means to pick up secretly small advantages for oneself. However, one cannot look at Shukhov's character from this aspect alone, because he usually values solid working-we can admire his zeal as a mason at the object TETS-and cannot understand why almost all men in his native village refuse to work in the kolkhose and prefer making money by fraud. When Ivan Denisovich cheats his fellow prisoners or the camp authorities, we can attribute his behaviour to the cruel circumstances of the camp, and so excuse it.

Whereas Shukhov has adjusted himself skillfully to the camp milieu without losing his human dignity, his fellow prisoner Fetiukov has humbled himself in such a way, that almost the whole brigade despises him. He begs for remnants of cigarettes, he even picks them out of spittoons, and keeps an eye on unfinished dishes. He is always trying to get some profit out of a situation or to ease his work, but mostly in vain. The word fetiuk [Ushakov (IV 1071), Academy of Science (IV 766)] means "lout" or "poor fool" [Dal's Dictionary (IV 533) mentions it as equivalent to grumbler or grouser]. Solzhenitsyn compares him with the jackal: "you couldn't beat Fetyukov when it came to scrounging [shakalit' means 'to scrounge"'], though he didn't have the guts to pinch anything"' (Hingley-Hayward, p. 90). Fetiukov reveals symbolically the human who is unable to maintain his dignity in the face of the brutal everyday life in the camp, loses his self respect and has hardly a chance to survive.

Solzhenitsyn contrasts him with Captain Buinovskii, the energetic 
navy officer who embodies the advocate of human rights and who is prepared to plead them in front of Lieutenant Volkovoi: "You've no right to strip people in the cold! You don't know Article Nine of the Criminal Code! You are not Soviet people," the Captain kept on at them. "You are not Communists!" (Hingley-Hayward, p. 38). Buinovskii's bold protest earns him ten days solitary confinement. The Captain is daring and temperamental, he "commands" also in the camp, and does not "shirk" hard labour, which he considers to be his duty. We know that Solzhenitsyn modelled this figure on his fellow inmate in the concentration camp, B. Burkovskii, ${ }^{15}$ but he invented an allegorical name-apart from Fetiukov, this may be the only purely allegorical one-because buinyi means "daring, bold, wild or vehement," e.g., Dal' (I138).

Despite his intellectual background, Buinovskii works with the other members of his brigade in the icy cold, whereas Tsezar' Markovich another member of Shukhov's brigade, had bribed the camp authorities with presents and got a comfortable job in the warm book-keeping office. Tsezar' Markovich treats his fellows in the brigade scornfully, because he has obtained more privileges than they, with the exception of the captain. He talks to nobody on serious matters. Even Brigadier Tiurin treats him with deference, in return for which Tsezar' manipulates the results of the daily quota. We know only Tsezar's first name and patronymic, but we can nevertheless presume that they belong also to the characterizing names. They sound strange to the reader, but they reveal probably the gap between him and the other brigade members. Before his imprisonment, Tsezar' held the distinguished position of a film producer, who was, however, arrested before he was able to finish his first film and this is the reason why he does not consider his fellow inmates as equals. He treats them unconsciously like his servants and lets them work for him, especially Shukhov. They are supposed to bring his meal to the office, since Tsezar' refuses to eat in the dining hall because of aesthetic reasons.

The critic Lakshin emphasizes Tsezar's isolation from the camp life: "The elegant aesthetics of Tsezar, his intellectual behaviour, the manner how he makes his pipe 'in order to stimulate in himself a strong thought and give something to it'-all this is in a sharp contrast with the ordinary prose of those efforts thanks to which a relative well-being and peace have been achieved; both enable the inmates to have pleasant reminiscences and talks close to the heart." 16

We can conceive of Tsezar' as a symbolic figure of the intellectual

${ }^{15}$ N.V. Pervushin, "The Soviet Writer Solzhenitsyn . ..," p. 18.

${ }^{16}$ V. Lakshin, "Ivan Denisovich, ego druz' ia i nedrugi”, Novyi mir, no. 1 (January 1964), p. 241 (quotation trans. by the author of this article). 
whose wealth enables him to disregard forced labour, but whose privileged position has been derived only from the satisfactory work of the brigade. Nevertheless, the author does not condemn him, but merely ridicules his naive egoism. While Tsezar' managed to obtain privileges by bribing the camp authorities, the baptist Aleshka helps everybody altruistically without getting any reward. In his stay in the concentration camp Aleshka recognizes the will of God and he is fully aware that according to his belief he has no right to protest against the cruelty of the camp life. He tries to exercise an influence on Shukhov and to convince him that material things are worthless before God, that only the idea of the good has value and the human is obliged to overcome the evil in himself and in the world by love. The practical Ivan Denisovich does not take his preaching too seriously. But, he never ridicules him and shows a great respect for his unselfishness and charity. Solzhenitsyn mentions only the baptist's first name, but we can assume that it is a characterizing name because its diminuitive suffix reveals his innocent character and ignorance of the world. As an example we can quote the following passages: "Alyoshka would never say no. He always did whatever you asked [p. 120]. Alyoshka came back too. He was always trying to please people but he never got anything out of it" (HingleyHayward, p. 202). Aleshka's religious views are not shared by his fellow inmates but we can be sure the strength of his belief will help him to survive his term in the concentration camp.

Another main figure in the short novel is Andrei Prokofevich Tiurin, the brigade leader, who negotiates very cleverly between the authorities and the prisoners and there are some hints that he could also belong to the characterizing names. He protects successfully their interests, but expects his brigade to give their best work in return and exploits them for his own privileges as brigade leader. Tiurin is only talkative when he is in a good mood and the inclemency of the icy winter does not show any effect on his tough, pock-marked face. It is not quite clear what the meaning of the name Tiurin could be: tiuria which means "watery soup" [Ushakov (IV 843) and the Dictionary of the Academy of Science (IV 596)] does not make sense here. According to Dal' (IV 452) tiurit' is a synonym to vrat' (to lie), putat' (to confuse) and molot' (to speak nonsense). In order to help members of his brigade Tiurin sometimes cheats the authorities; tiurit' in the sense of putat' (to confuse) would be possible. Indeed we know that Solzhenitsyn studied Dal's dictionary very carefully when he was an inmate of a concentration camp himself. ${ }^{17}$ However, it is vague whether Tiurin could be considered as a symbolic figure.

${ }^{17}$ Interview with B. Burkovskii in Izvestiia (January 15, 1964). I quoted from N.V. Pervushin's article, “The Soviet Writer. ...," p. 18, since this issue of Izvestiia was not available. 
Another figure is Gopchik, the favourite of the brigade. He shows a boisterous vitality, e.g., during the work at the object TETS. Despite his young age he adjusts to camp life very quickly and Shukhov is surprised by his ability to profit from the carelessness of other prisoners. He does not want to share food from his parcels with his fellow inmates, so he usually eats it during the night. His name could be associated with gop [according to Dal' (I 375) it means "jump"; according to Ushakov (I 596) and the Dictionary of the Academy of Science (I 443)-"a challenge to jump"], the syllable chik is a diminutive suffix. For the name Gopchik also the phonetics are important; we meet the name at least once in the form Gopchik-Khlopchik, and it is the only one in One Day formed according to phonetical principles. Another possible etymon is khlopchik, a Ukrainian word meaning "little boy."

Needless to say, the guards and the camp authorities oppressing the prisoners appear to be their enemies. Lieutenant Volkovoi is presented as the devil of the camp and the author himself gives us a hint to his characterizing name: "Even the Commandant was scared of Volkovoi-let alone the prisoners and warders. Not for nothing was he called Volkovoi. And he always looked at you like a wolf' (HingleyHayward, p. 35). Volkovoi embodies arbitrariness and brutal exploitation. In previous years he had whipped the prisoners in the jail personally-and like a hurricane he scatters crowds of inmates. His name is not purely allegorical, because he does not reveal only one characteristic feature. It can be derived only from volk ("wolf"), but the expression volkovoi which I found in Dal's Dictionary (I 233) would be senseless because it means a hunter imitating the howling wolf.

A symbolic figure could be seen in the slim Tatar, a guard, always trying to find opportunities to put the prisoners into jail or to press for special labours. He personifies the evil in the camp along with Volkovoi. Though he remains nameless, the author is speaking about him only as the Tatar; we can nevertheless assume that his name is also a characterizing one because the Russians mention in their proverbs the ill nature and perfidy of the Tatarians, e.g., "nezvannyi gost khuzhe zlogo Tatarina" ("an uninvited guest is worse than a malicious Tatar") and Solzhenitsyn points out his low voice, his unyielding character and his insensibility even for the icy cold: "Their shoulders were hunched and their coats buttoned up and they all felt cold, not so much because of the freezing weather as because they know they'd have to be out in it all day. But the Tatar in his old overcoat with shabby blue tabs walked steadily on and the cold didn't seem to bother him at all' (p. 8).

A swine among the prisoners is Shkuropatenko, who guards the wooden houses for the camp authorities so carefully: "Shkuropatenko was no one in particular, just an ordinary prisoner, but he was paid for guarding the prefabs and stopping the prisoners from pinching them" 
(p. 64). Shkuropatenko could be derived from shkura ("skin"), meaning a man drawing off the skin from others or from shkuriat' (Dal' [IV $638]$ ), to chase away or urge.

Persons without characterizing names are either minor figures who appear only once, e.g., Volkovoi's deputy Priacha or the assistant camp physician Vdovushkin, or those who cannot be considered as symbolic figures, e.g., Tiurin's deputy Pavlo-Zhenka Klevshin, the hero of the concentration camp Bukhenwald or the Latvian Kilgas. We can state that Solzhenitsyn's characterizing names are a product of his concise style which does not allow lengthy descriptions, and that the act of naming enables the author to hint at the characteristic features of individuals.

Finally we can raise the question, had Gogol, the master of characterizing names in Russian literature, any influence on Solzhenitsyn's naming or can we trace even parallels in the techniques or usage of personal names in the works of Solzhenitsyn and Gogol?

Gogol's names consist of two main groups: to the first group belong personal names which give us some hints at the profession or the character of Gogol's figures, e.g., the names of the policemen in the Government Inspector: Pugovitsyn (probably from the word pugovitsa: "uniform button"), Svistunov (from the word svist or svistun: "whistle or sly dot"), Derzhimorda (derzhi mordu), a person holding the tongue of others, Ukhovertov (ukho vertet') a man who turns his ears around or is spying around or the name of Khlestakov, the lying gossip (khlestat' means rather lying or chatting than whipping). ${ }^{18}$ To the other group of names, where not only the meaning, but also the sound pattern is important (they exist sometimes as double names), belong the judge Liapkin-Tiapkin (whose name means "negligent," or "gossiping"), the mayor Skvoznik-Dmukhanovskii (skvozniak-"current [draught] of air," and dmukhaty, in Ukrainian "to blow, to puff"), Chichikov, Bobchinskii, Dobchinskii, etc. Some of these names have been formed by the duplication of syllables which also has been used by Gogol for the characterization of his heroes. ${ }^{19}$ We can safely say that, in forming his names, Gogol took into consideration not only etymology, but also phonetic aspects. Most of the names are comic, their origin stemming from a tradition in Russian comedy and in the preference of the Ukrainians to nicknames. ${ }^{20}$ It would be overdone to state that we can trace parallels in the names of both authors. The only similarity could be found in Gogol's double names, e.g., Liapkin-Tiapkin and in the nickname Gopchik-Khlopchik which is the only forming of a name in

${ }^{18}$ W. Kassack, Die Technik der Personendarstellung bei Nikolai Vasilievič Gogol (Wiesbaden, 1957), p. 15.

${ }^{19}$ Ibid., pp. 17-18.

20. Ibid., pp. 14-16. 
Solzhenitsyn's short novel according to phonetical principles. Nicknames, however, have been hardly used by Solzhenitsyn and both authors scarcely use allegoric names (in One Day the only exception are Buinovskii and Fetiukov). Persons without characterizing names are either minor figures, e.g., the female heroines in Gogol's Mirgorod or St. Peterburg Tales or figures without a symbolic meaning, e.g., Pavlo, Kilgas or Klevshin in One Day.

Summing up, we can mention that Solzhenitsyn's naming is less striking and simpler than Gogol's for whom the phonetics played almost the same role as the etymology; we cannot speak about parallels in the names of both authors, both only employed a similar technique of using names revealing the character of a person.

\title{
Laurentian University
}

\section{NECROLOGY}

The Secretary-Treasurer regretfully announces the deaths of the following members:

\author{
Charles Didway \\ Eckhard Ruttner \\ Frances Stillman
}

